\title{
The basement complexes in Italy, with special regards to those exposed in the Alps: a review
}

\author{
1 Dipartimento di Scienze della Terra, Università di Milano and Istituto per la Dinamica dei Processi Ambientali, Consiglio Nazionale delle \\ Ricerche, Via Botticelli 23, 20133 Milano, Italy. \\ 2 Dipartimento di Mineralogia e Petrologia, Università di Padova, Corso Garibaldi 37, 35137 Padova, Italy. \\ 3 Istituto di Geoscienze e Georisorse, Consiglio Nazionale delle Ricerche, Sezione di Padova, Italy.
}

\begin{abstract}
Most of the sedimentary rocks occurring in Italy are post-Carboniferous. All what lies below is considered basement, mostly metamorphic or igneous. Understanding the pre-Carboniferous evolution depends on the reconstruction of the sedimentary, metamorphic and igneous evolution of the basement. In general, the basement sedimentary protoliths were Lower to Middle Paleozoic siliciclastic rocks, while the igneous protoliths belong to an Ordovician cycle. The prevailing metamorphism, from very-low grade to granulite facies, is Variscan. It was followed by the formation of large amounts of granitic melts.
\end{abstract}

\section{Introduction}

The term "basement complexes" (BCs) is used here for the set of rock complexes underlying the post-Variscan unconformity (the age of the bottom of the related volcano-sedimentary cover being various, ranging in most cases from Upper Carboniferous to Lower Trias). These basement complexes show structural vestiges of older deformational events, and the effects of older depositional, erosional, metamorphic and magmatic events. The related old features are more or less modified by younger deformational and thermal overprints. The basements described here are mostly metamorphic and crosscut by Upper Paleozoic "younger granites"; however some unmetamorphosed old Paleozoic sequences are also present (but not described here).

Basement complexes in Italy are exposed in many places, as shown in Figure 1a, and with more details in Figures $1 \mathrm{~b}$ to $1 \mathrm{~d}$.

To the North, along the Alps, BCs occur as the deepest lithostratigraphic element in each of the main structural complexes (or nappe systems) making up the Alpine chain: the Helvetides, the Pennides, the Austrides (or Austroalpine) and the Southern Alps (or Southalpine) (Figure 1b). In the peninsular and insular part of Italy, along which the Apennine mountain chain develops, BCs are exposed in Tuscany (surroundings of Florence in Figure 1a) and, more to the south, in Calabria and Sicily. The latter BCs are part of the so-called Calabria-Peloritani Terrane (Figure 1c). Finally, BCs dominate as a component of the Sardinia island (Figure 1d), where they are classified in Axial Zone, Nappe Zone and External Zone.

The Calabria-Peloritani Terrane is a tectonic juxtaposition of a $\mathrm{N}$ subterrane (the Sila and the Serre massifs) and a $\mathrm{S}$ subterrane (Aspromonte massif and Peloritani Mts).

As regards Tuscany, the data from the small and scattered occurrences are integrated with subsurface data obtained from drillholes in the Larderello geothermal field.
The main features of the Italian BCs are summarily outlined here, in the narrow limits of the necessarily small number of available pages. The literature is extremely large and, in order to save space the quotations throughout the text and the list of references are reduced to the minimum possible. The main source of data utilized here are the review volumes listed below. When single papers are quoted in the text marked by an asterisk, they are not included in the list of References, but their full citation may be found in one or more of the listed References. Anyway, the full list of the cited papers may be requested to the authors of the present paper.

The main source of data used here are: Flügel et al. (1987), Sassi and Zanferrari (1989), Carmignani and Sassi (1992), Peccerillo and Sassi (1994), von Raumer and Neubauer (1993), Frey et al. (1999), Carmignani et al. (2001), Vai and Martini (2001), Sassi et al. (2003) and, as regards radiometric geochronology, Anonimous (1985) for all age data available in Italy until 1985, and Thöni (1999) for more recent data on the Alps.

It is worthy to point out that the rock complexes occurring in the Alps cross the State boundaries with Austria, France and Switzerland. Furthermore, all other Italian BCs also attracted the attention of numerous not-Italian scientists. Therefore the description given below is also based on their numerous and significant contributions.

Both the discussion and the list of papers quoted in the text are more detailed for the BCs of the Alps than for the other BCs occurring in Italy. This fact reflects not only the literature, which is much more abundant for the Alps, but the personal experience of the authors of the present review. More specific data can be found in Pandeli et al. (1994) and Carmignani et al. (2001b*) concerning Tuscany, in Carmignani et al. (2001) and Sartori (2001*) as regards Sardinia, in Bonardi et al. (2001*), Rottura et al. (1990*, 1993]), Grässner and Schenk (2001), Grässner et al. (2000*), Caggianelli and Prosser (2002) as regards the Calabria-Peloritani Terrane.

\section{General structural setting}

The Italian mountain chains (Alps, Apennines), in which the BCs represent the oldest rocks (mostly Lower Paleozoic), formed during the Alpine Orogeny (mainly Tertiary). The largest BCs exposures occur in the Alps, i.e. in the complex, nappe structured chain which formed due to the closure of the Tethys ocean and the collision of the European plate with the African plate (specifically the Apulian or Adria microplate). As mentioned above, BCs occur, with different features, in each of the four main structural domains of the Alps. Before plate collision, the Helvetic and Pennidic BCs were part of the European plate, whereas the Austridic and Southalpine BCs were both part of the African plate.

Paleomagnetic and structural data, as well as lithological affinities, indicate that Sardinian BCs were a continuum with the S-European BCs and shared with them (particularly with Catalonia and Provence) the same evolution until Oligocene, before getting detached and drifting southwestwards to the present position. Struc- 


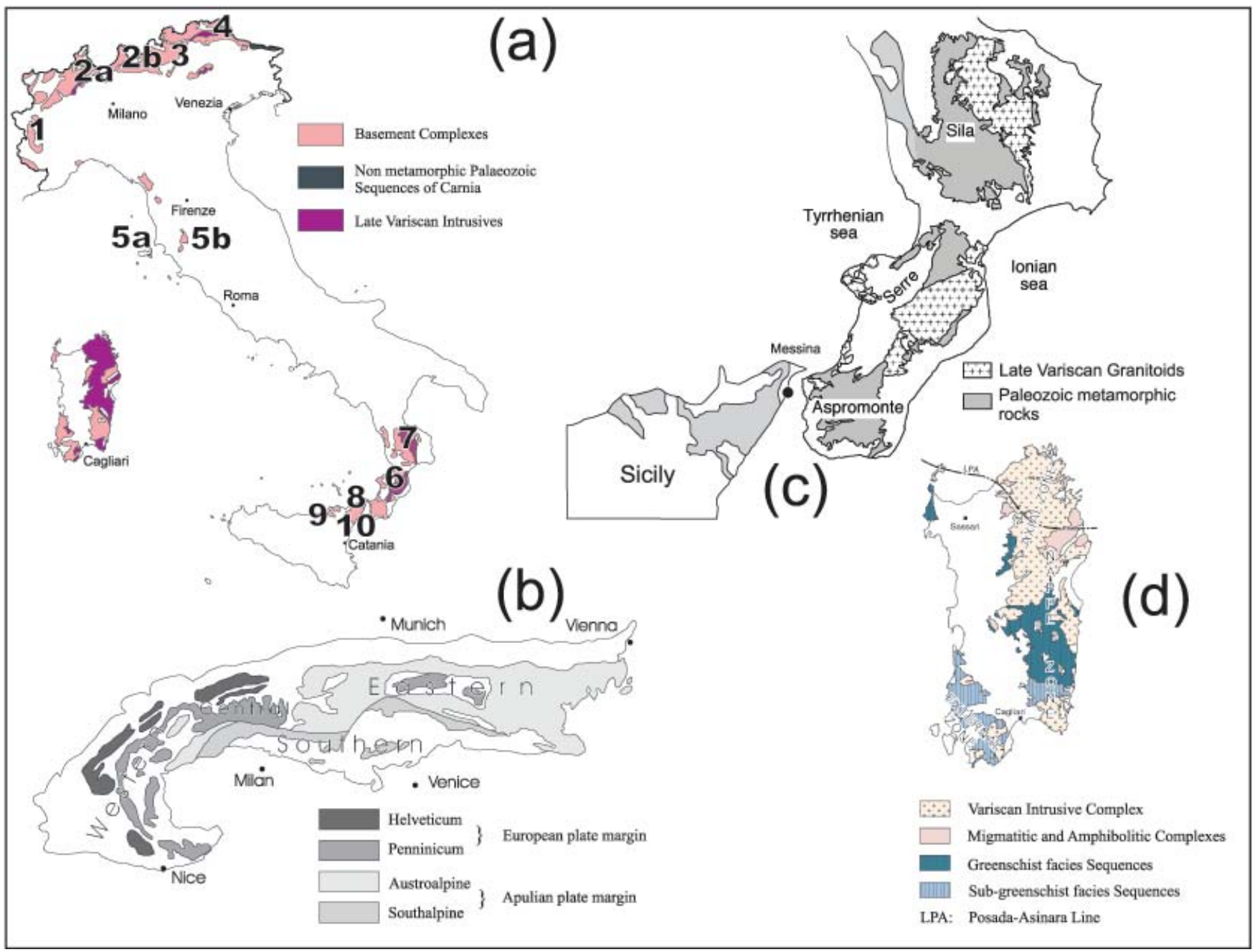

Figure 1 (a) Location of the basement complexes exposed in Italy. (b) Sketch map of the main structural units making up the Alps: the different grey areas are basement complexes in the different structural units (taken from Spiess et al., 2001, modif.). (c) Sketch map of the basement complexes of the so-called Calabria-Peloritani Terrane, i.e. in the southernmost part of the peninsular Italy and the northwest corner of Sicily (taken from Prosser et al., 2003, modif.). (d) Geological sketch map of Sardinia, showing that basement complexes outcrop over a dominant area of the island (taken from Carmignani et al., 2001, modif.).

tural data and lithological affinities suggest that the Ligurian Briançon units (Western Alps) also belonged to the SardiniaProvence structure.

The Calabria-Peloritani Terrane is a fault-bounded exotic terrane, the origin of which is still debated, and probably is the result of amalgamation of two or three microterranes. An African origin has been suggested for the $\mathrm{N}$ sector, and a possible European origin for the $\mathrm{S}$ one.

BCs of Sardinia, Tuscany and Calabria-Peloritani Terrane were involved in the "alpidic" (Mesozoic and Tertiary) geodynamic precesses which took place in the Central-Western Mediterranean, but Sardinia escaped Alpine metamorphism.

As pointed out below, all BCs occurring in Italy underwent the Variscan thermal and tectonic events (with local exceptions: see below). Similarly to all other South-European basement terranes, they represent polydeformed, sometimes polymetamorphic domains which, since the Lower Paleozoic, underwent a complex and still debated history of drifting and amalgamation processes. They acquired the present setting due to Pre-Variscan, Variscan and Alpine events.

\section{Lithology, stratigraphy, geochemistry}

Most rock types indicate a shallow crustal nature, but rocks referred to an intermediate to deep crust occur both in the Alps (the so called Ivrea-Verbano Zone) and in Calabria. Variously aged and more or less retrogressed eclogite lenses and boudins locally occur.

The shallow crustal sequences consist of metapelitic-psammitic rocks of various metamorphic grade with lenses or intercalations of leucocratic gneisses, amphibolites, acidic and basic metavolcanics and some marbles.

The deep crustal Ivrea-Verbano Zone consists of high-T amphibolite and granulite facies metamorphic rocks derived from pelites, mafic rocks and limestones with lenses of ultramafic rocks. The presence of lenses of spinel lherzolite near a large layered mafic pluton (Rivalenti et al., 1984) induced in the past many authors to consider the Ivrea-Verbano Zone a crust-mantle transition (Mehnert, 1975*; Zingg, 1983*). See also Schmid (1993*) and Quick et al. (1994*, 1995) for an overview on the Ivrea Zone. The Variscan deep crustal sections exposed in Northern Calabria (Sila and Serre) consist of granulites, migmatites, metapelites, metaultramafics, metabasites, and some marbles. In Sardinia and Ligurian Alps, eclogites affected by granulite overprint and associated to migmatites possibly represent deep crustal sections. 
The sedimentation age of the protoliths of the metasedimentary sequences making up the bulk of the BCs has been determined by microfossil in very-low grade rocks. Sedimentation age ranges from Cambrian to Devonian. Sassi and Zanferrari (1989) present a general review of all biostratigraphic data available at that time for all BCs occurring in Italy. More recent biostratigraphic data concerning the very-low to low grade Austridic BCs of the Alps can be found in several papers in von Raumer and Neubauer (1993). In the metamorphic BC of the Southern Alps, only two fossil findings have been reported: Cambrian acritarchs in the most southeastern outcrop of the Southalpine BC (Sassi et al., 1984*; Kalvacheva et al., 1986*) and Ordovician-Silurian palynomorphs in the central Southalpine BC (Gansser and Pantic, 1988*).

In the medium to high grade metasedimentary sequences, a Lower Paleozoic sedimentation age of the protoliths is assumed. Precambrian age values have been only obtained radiometrically from detrital zircons in metasediments and in some zircon xenocrystals inherited in Paleozoic igneous rocks. However, some rocks and deformational events in the Silvretta Nappe are reported as Precambrian (Maggetti and Flisch, 1993*).

A special mention deserve the metabasites (mostly amphibolites, but also eclogites and metaultramafics), which occur in every $\mathrm{BC}$, and which have been extensively used for the reconstruction of the evolutionary paths and geodynamic interpretations: e.g., in the Alps: von Raumer and Neubauer (1993, and refs. quoted therein), Miller and Thöni (1995*); in Sardinia: Carmignani et al. (2001 and refs. quoted therein); in the Calabria-Peloritani Terrane: Bonardi et al. (2001*, and refs. quoted therein). Eclogites are commonly reported as pre-Alpine and sometimes pre-Variscan, but in the Austrides of the Eastern Alps evidence has been found that Eoalpine eclogites also occur (Miller and Thöni,1997). In the Ligurian Alps, a glaucophane-bearing eclogitic overprint occurring in the T. Visone Unit is considered of possible Eo-Alpine age.

Data and considerations on the pre-Cambrian development of the crust of the European Variscides in and outside the Alps can be found, e.g., in Gebauer (1993*).

As regards geochemical aspects, a large amount of data exists, mainly concerning igneous and orthometamorphics. In addition Sassi et al. (2003) present and discuss the abundance of 55 chemical elements and petrovolumetric models of the crust in 10 type areas from the BCs of Italy, with some geophysical and petrophysical data (see their location in Figure 1a).

\section{Metamorphism}

\section{The Alpine Overprint}

In many cases, the present metamorphic features of BCs are Paleozoic, in other cases Alpine metamorphism(s) affected various BCs even strongly. From this point of view, three extreme situations occur:

- BCs in which the present metamorphic features are Alpine, and the characters of the pre-Alpine metamorphism(s) cannot be defined: this is the case, e.g., of the main part of the Pennidic BCs in the Central and Eastern Alps;

- BCs in which an Alpine metamorphic overprint occurs, but the metamorphic pre-Alpine features can still be defined: this is the case, e.g., of parts of the BCs in the Austrides, or parts of the BCs of Calabria-Peloritani Terrane and Tuscany;

- BCs which were localized outside the Alpine metamorphic domain: e.g., the BCs of Sardinia and the Southern Alps.

Alpine metamorphic evolution developed in two multistage events. The complexity of such a scenario was increased by lateAlpine tectonic, post-metamorphic dismembering, which disconnected and variously displaced $\mathrm{BC}$ terrains. The features of the Alpine overprints are disregarded here.

\section{The Variscan metamorphism}

It affected all BCs occurring in Italy. The only exception known are: (i) to the west, the occurrence of some units in the Briançon basement (Desmons, 1992*); (ii) to the east, the occurrence, $5 \mathrm{~km}$ underneath Venice, of Ordovician (460-470 Ma on euhedral zircons) granodiorites (Meli and R. Sassi, 2003). We are inclined to consider as local but significant details these two situations, which do not weaken the concept that Variscan metamorphism regionally dominated over all terrains from which the south-European BCs derived.

As regards the features displayed by the Variscan metamorphism, it has been reported as a low pressure event in some areas (e.g. in the Austridic BCs of the Eastern Alps consistently with the common occurrence of andalusite and cordierite in rocks of appropriate bulk composition and metamorphic grade), and as a Barrovian-type event in other areas (e.g. in the Western-Central Alps, in which however sometimes a low-pressure, late Variscan metamorphic overprint occurs: Colombo and Tunesi, 1999). In the last decade, evidence was found of the existence of an early (about 350 Ma), HP stage of the Variscan metamorphism (Miller and Thöni, 1995*; Hauzenberger et al., 1996*; Godard et al., 1996*).

In the Central-Western Southern Alps the main metamorphic phase was followed by a retrograde metamorphism which occurred during uplift and erosion. This overprint, generally not pervasive, was particularly intense along late-orogenic shear zones (Colombo and Tunesi, 1999).

The age of the metamorphic peak in the Ivrea-Verbano Zone is early Permian (Boriani and Villa, 1997). It has been related to the thermal effect of the intrusion at the base of the crust of the mafic Ivrea body in a late-orogenic extensional geodynamic regime (mafic underplating).

In the Axial Zone of Sardinia, the Posada-Asinara Line, a milonitic belt including relics of eclogites, is interpreted as a possibile Variscan oceanic suture, i.e. a part of the suture between Armorica and Gondwana. The amphibolite facies paragneisses and micaschists along it include amphibolite lenses preserving relics of a HP metamorphism, specifically relics of granulitic and eclogitic mineral assemblages. It separates two metamorphic domains: a Migmatitic Complex to the $\mathrm{N}$ and a Barrovian type, mainly Amphibolite Facies Complex to the S. In the Nappe Zone, the synkinematic Variscan metamorphism is of Barrovian-type, mainly in the greenschist facies, locally in the subgreenschist facies, or in the amphibolite facies. A postkinematic, low pressure overprint is well documented both in the Axial and in the Nappe zones. In the External Zone metamorphism, where detectable, is of very-low or low grade (Carmignani et al., 2001).

The Calabria-Peloritani Terrane includes various types of Variscan metamorphics, from weakly metamorphosed sequences to upper amphibolite facies rocks, granulites and migmatites. Relics of eclogites also occur. In the greenschist facies pelitic sequences, the mineral associations do not give definite indication of the $\mathrm{P}$ character. In the medium to high grade rocks, an early Variscan metamorphism under medium pressure conditions followed by a widespread low $\mathrm{P}$ overprint has been suggested (Schenk, 1990*).

The BCs in Tuscany mostly consists of Variscan low-grade sequences. A late Variscan, low-P/high T overprint locally occurs. Records of an early, barrovian-type stage of medium to high grade are reported (Pandeli et al., 1994).

\section{The pre-Variscan metamorphism(s)}

In some sites, as for example in the Austrides of the Eastern Alps, relics or traces of an older, Paleozoic (ca. 470-500 Ma), "Caledonian" metamorphic event have been reported (e.g. Sassi and Schmidt, $1982 *$; Ebner et al., 1987*; Frisch et al., 1987*; Sassi et al., 1987*; Hoinkes and Thöni, 1993*), although the matter is still debated (e.g. Schulz et al., 1993*). Some pieces of controversy deal 
with different interpretations of observed data, other on the name "Caledonian" (the use of "Cadomian" or "Panafrican" could make discussion smoother). Matte (1991) considers this event as EoVariscan, and refers it to the closure of the Rheic oceanic basin. The main Variscan metamorphism is instead interpreted as a fully intracontinental event.

In any case, the matter of facts is that, during upper Ordovician, an enormous amount of acidic melts (in some units more abundant than the Variscan ones) was formed through crustal melting and emplaced both as plutonic bodies and as volcanic products over a very large area. The degree and the extent of the regional metamorphism that may have accompanied or preceded this magmatic event are not well established. A few traces that may suggest a preVariscan metamorphic event are: (i) the occurrence in Oetztal of fragments of banded, partly amphibolitized eclogites within some marbles affected by low-pressure Variscan metamorphism; (ii) the occurrence in the Upper Ordovician orthogneisses of partly amphibolitized eclogites (W. Southern Alps) and of banded xenoliths, the folded foliation of which does not fit that of the host orthogneisses (E. Austrides). Furthermore, according to Hoinkes and Thöni $\left(1993^{*}\right)$, strong radiometric indications for a Caledonian anatexis accompanied by the formation of fibrolite support the view of a dominant Caledonian metamorphism in the Oetztal-Stubai BCs (E. Austrides).

It must be noted, however, that in the W. Southern Alps (Strona Ceneri Zone) Boriani et al. (1990b and 1995) report evidence that, at the moment of the intrusion of the Ordovician granites, the protoliths were unmetamorphosed.

In Sardinia, it is not possible to exclude the occurrence, in the Migmatitic Complex occurring in the NE part of the island, of preCambrian sequences preserving a pre-Variscan structuration. Anyway, a "Caledonian" event (but not including metamorphism) is documented at least in the SE Sardinia by an angular unconformity and a Middle Ordovician calc-alkaline magmatism (Carmignani et al., 2001).

In the Calabria-Peloritani range, some authors consider the eclogite facies relics and some granulites as representing the original, Cadomian or intra-Cambrian basement of the low-grade terraines. Data and interpretations about the metamorphic evolution recorded in the continental crust of the Calabria-Peloritani Terrane may be found in Paglionico and Piccarreta $\left(1978^{*}\right)$, Schenk (1990*), Caggianelli et al., (1991*), Grässner and Schenk (2001) and Fornelli et al. (2002) .

\section{Magmatism}

The Mesozoic and Tertiary igneous events are obviously disregarded here, because their products lie over the BCs (when emplaced by volcanic mechanisms) or crosscut them (when emplaced by intrusion). For the same reason, the post-Variscan, Upper Paleozoic, mainly acidic volcanics (e.g. the so-called "Bolzano Rhyolitic Plateau") are not considered here; they do not belong to any BCs, but lie over them, belonging to their non-metamorphic cover. Anyway, data on them may be found, e.g., in Cortesogno et al. (1998*), and Rottura et al. (1998*).

\section{Late Variscan magmatism}

Plutonism: Almost all BCs exposed in Italy are crosscut by granitoid intrusions, which were emplaced in the late stages of the Variscan before the above mentioned Permo-Triassic unconformity. They produced contact metamorphic aureoles on the surrounding, already metamorphic basement rocks. The literature on this subject is extremely abundant and cannot be easily summarized in this article. For the Alps Bonin et al. (1993*) wrote an extended and interesting review paper to which the reader is invited to refer. Granitoids are widespread in all tectonic units in most of which they experi- enced a pervasive Alpine overprint. In the Southalpine they were not affected by metamorphism and are therefore less problematic as far as age determinations and geochemical characters are concerned. The age of intrusion spans over a large time range. Their geochemical and isotopic signature point to a complex evolution of magma source and geodynamic regime. The oldest granitoids are peraluminous and reflect crustal thickening and more or less wet melting conditions. They are accompanied by high-K mafic magma. The Lower to Middle Carboniferous magmas are high- $\mathrm{K}$ calc-alkaline and reflect post-collisional rapid uplift and erosion. They are followed by Late-Carboniferous almost alkaline associations emplaced in a "Basin and Range" tectonic regime. Late-Carboniferous to Early Permian calc-alkaline (sometimes high-K) granitoids are reported to reflect a convergent setting. As far as the Southalpine is concerned, this interpretation conflicts with that given by Pinarelli et al. (2002*), who explain those characters with an origin of the parent mafic magma from an enriched mantle. Mid-Permian to Triassic A-type plutonic/volcanic complexes conclude this long story of granitoid magma formation. They are related to the post-orogenic continental consolidation of the European plate.

In Sardinia, the so-called "Sardinian Batolith" is exposed over a large part of the island and extends to a large part of Corsica, making up one of the most important batholiths of the European Variscan Chain. It has a composite structure, and its emplacement took place over a 40 MA time span, related to an extensional regime. Several rock types are represented in it (mainly granodiorites and monzodiorites related to a calc-alkaline association (Carmignani et al., 2001, and quoted liter.).

In the Calabria-Peloritani Terrane, Late Carboniferous-Permian granitoid intrusions occur mostly in the $\mathrm{N}$ sector (Figure 1c). This magmatism shows a calc-alkaline character, and includes metaand per-aluminous plutons emplaced at different levels from the lower to the upper crust (Rottura et al., 1990*, 1993*; Ayuso et al., $1994 *$ )

\section{Upper Ordovician magmatism}

During Upper Ordovician a very strong, mainly acidic magmatic activity took place, both under plutonic and volcanic conditions. In the Eastern Alps, the possible co-genetic relation between volcanics and plutonics was first proposed by Peccerillo et al. $(1979 *)$ and Bellieni and Sassi $\left(1981^{*}\right)$, who also suggested the idea of an "Upper Ordovician Granite-Rhyolite Association", and further supported by Mazzoli and R. Sassi $(1992 *)$. Such a suggestive hypothesis, although consistent with the presently available data, still requires further analytical support.

In Sardinia, Ordovician magmatic rocks are also reported in some structural units. They include both plutonics (granodiorites) and acidic plus basic volcanics. The protholiths of the acidic orthogneisses are also referred to the Ordovician magmatic cycle (Carmignani et al., 2001, and quoted liter.).

Some felsic metavolcanics occurring in Northern Calabria are considered of Ordovician age. A widespread Middle Ordovician, acidic volcanism (metaignimbrites) is also documented in Tuscany, as well as late Ordovician intrusive metabasites.

\section{Plutonism}

Due to the Variscan, and sometimes also Alpine overprints, the products of this plutonism are presently orthogneisses, the chemistry of which ranges mainly within the fields of granites and granodiorites, but also tonalites and quartz diorites. In the Eastern Alps a huge amount of melts is related to this event. They display a calc-alkaline affinity. $\mathrm{SiO}_{2}$ wt $\%$ covers almost continuously the $62-77 \%$ range The more acidic rock types show a higher HREE fractionation. Negative Eu anomaly is a common character. The lack of genetically related basic rocks is to be pointed out. All data available indicate an origin by a regional crustal anatexis. However, the Ordovician metagranitoids outcropping in the Western Southern Alps show evidence 

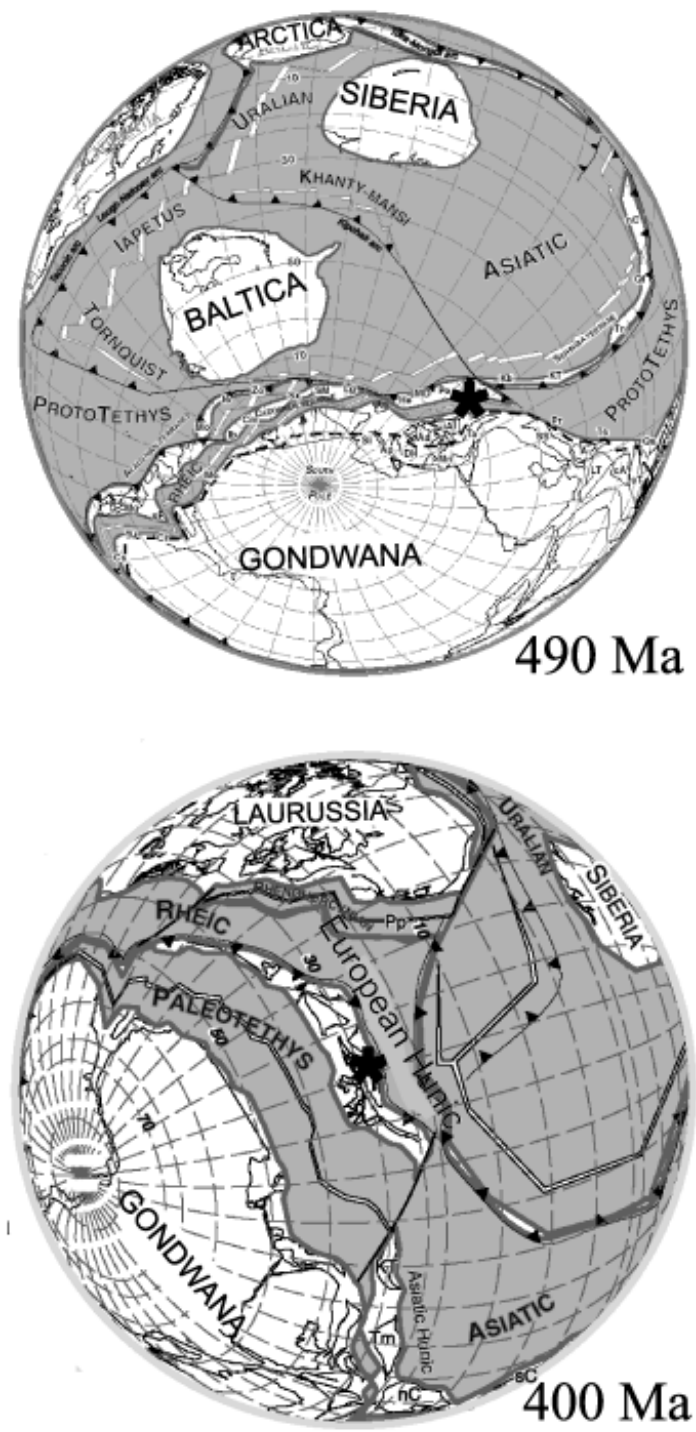
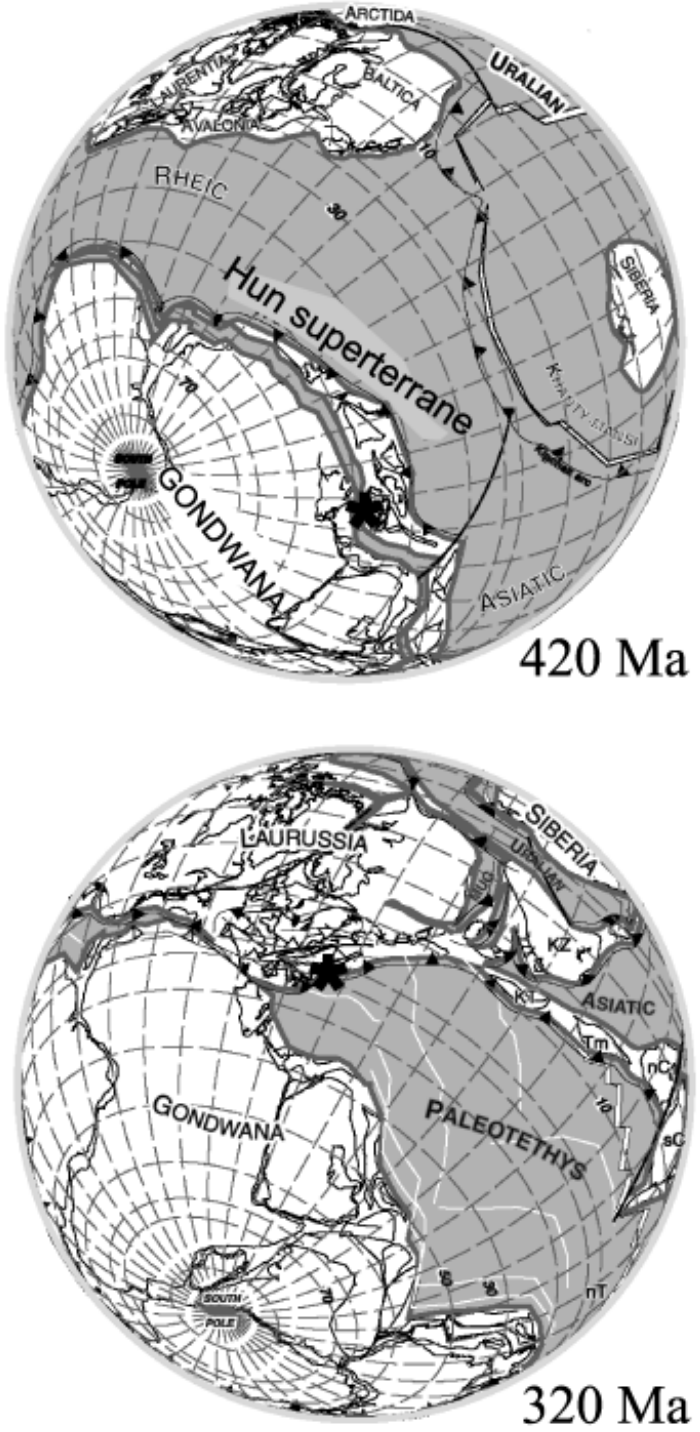

Figure 2 Plate drifting from 490 to 320 Ma ago according to Stamplfit et al. (2002), and related progressive migration of the Hun Superterrane from the margin of Gondwana to the margin of Laurussia. Asterisk shows roughly the location, in different times, of the microplates from which the basements occurring in Italy derived (a collage of the Figures 2 and 3 from Stamplfie et al., 2002).

of crust-mantle interaction, and are considered as records of a magmatic activity developed in a convergent plate boundary environnement (Pezzotta and Pinarelli, 1994*; Boriani et al., 1995*). Radiometric data (mostly $\mathrm{Rb} / \mathrm{Sr}$ on large-sized rock samples) define a range of $470-420 \mathrm{Ma}$.

In Sardinia, worth of mentioning are the granodioritic orthogneisses of Capo Spartivento, in the southernmost part of the island (external Zone), and the similar orthogneisses in the north part of the Nappe Zone.

\section{Volcanism}

One of the most striking features in these basements is the widespread occurrence of mainly acidic volcanics and volcanoclastics which expanded, probably as ignimbrites, over large areas during Upper Ordovician (and somewhere Middle Ordovician). These rocks, then, underwent the Variscan metamorphism, which changed them into the so-called "porphyroids" in the low-grade areas, and in stratiform white gneisses in higher metamorphic grade areas. In every BCs these metavolcanics represent a well detectable key-horizon, also useful in inter-regional correlations.
In the Eastern Alps, they occur both in the South-Alpine and in the Autridic BCs. In the South-Alpine BCs, where they have been dated radiometrically on zircons (ca. $480 \mathrm{Ma}$, Meli and Kloetzli, $2001^{*}$ ) geochemistry and petrology based on parameters insensitive to later re-mobilization, indicate a crustal anatectic origin through dehydration melting reactions, in a possible late to post-orogenic scenario (Meli, 1998*).

The low grade Austridic BCs also record, in different areas, other Paleozoic volcanic processes (the products of which are obviously metamorphic). According to Loeschke and Heinisch (1993*), they are within-plate alkali basalts of Ordovician, Silurian, Devonian and also probably lower Carboniferous age, indicating a long-lasting, Paleozoic, extensional process. The protoliths of the amphibolites occurring in the medium to high grade metamorphics may be partly related to this process.

In Sardinia, in some areas of the Nappe Zone, four Ordovician volcano-sedimentary metamorphic complexes have been defined, including acidic metavolcanics, and intermediate and basic metaepiclastites and metavolcanics. 


\section{Pre-Ordovician events}

In the Western Southalpine basement, like in other parts of the Variscan belt, a peculiar bimodal lithological association is found, the Leptyno-Amphibolitic Group (LAG), which consist of alternating $\mathrm{cm}$-thick, fine-grained leucocratic and melanocratic layers of amphibolite facies metamorphic rocks, with lenses of metagabbro, retrogressed eclogites and ultramafites. Their geochemistry is compatible with a derivation from back-arc tholeiites. These LAG may well represent the reworked products of an early Variscan suture, in which ophiolitic remnants that underwent HP metamorphism in a subduction zone have been incorporated in turbiditic sediments derived from back-arc bimodal volcanics before the intrusion of the Ordovician granites that cut across this unit (Giobbi Mancini et al., 2003). A similar situation seems to occur in the Ligurian Briançon units (Western Alps).

As regards the older history, records of major pre-Cambrian crust-forming events have been detected by radiometric dating of zircons: see Gebauer (1993*) for a review and discussion.

Cambrian sedimentary sequences (partly very-low grade metamorphics) are widespread in SW Sardinia. Furthermore, the protholiths of the Migmatitic Complex occurring to the North of the Posada-Asinara-Asinara Line are condidered as pre-Cambrian, and therefore should record pre-Cambrian events deeply oblitareted by the Variscan, high grade, polystage metamorphism and anatexis (Carmignani et al., 2001).

The possible existence of pre-Ordovician events in the Calabria-Peloritani Terrane is documented by zircon age values in the range 550-622 Ma obtained from metabasites and acidic orthogneisses in Serre and Aspromonte (Schenk, 1990*; Senesi, 1999*). In Tuscany, boreholes in the geothermal field reached gneisses and micaschists underlying Cambro-Ordovician rocks.

\section{The BCs in Italy in the context of the Paleozoic organization of the European basements}

As pointed out above, all BCs occurring in Italy acquired the present setting due to pre-Variscan, Variscan and Alpine events. These events are to be considered as critical records of a continuous plate drifting and various amalgamation processes. Such an evolution was common to all South-European BCs at least since Paleozoic.

General models of this Paleozoic evolution of the European BCs are available in the literature (e.g. Stampfli et al., 2001*; Vai, 2001*; von Raumer et al., 2002; Stampfli et al., 2002), The matter is still relatively fluid and rapidly evolving, although some pieces of the mosaic seem to be definitely established. However, significant pieces of knowledge are still lacking or poorly known, including specific field data. Furthermore, the interpretation and better dating of some specific igneous and metamorphic events are needed, in order to strengthen, better constrain or modify the various existing models. This is particularly necessary for the BCs occurring in Italy, the correlation among which and with other European BCs is at a rather early stage.

In a very simplified way Figure 2 shows, as an example, the model proposed by Stampfly et al. (2002). The asterisk roughly indicates the location, in different times, of the microplates from which the basements occurring in Italy derived. 490 Ma ago the South European basements were localized at the Gondwana margin, separated by the Early Rheic ocean. $420 \mathrm{Ma}$ ago all continental fragments making up the present Sud-European BCs belonged to the Hun Superterrane, which progressively drifted towards Laurussia and finally, $320 \mathrm{Ma}$ ago, accreted to it. All these basements display not only similarities because of their common Paleozoic history, but also peculiarities which depend on their individual evolution. The main goal of the present research in this field is to focus on both the similarities and the peculiarities, in order to better defining such type of models, and to contribute to their interdisciplinary discussion.

\section{Acnowledgements}

Critical reading by Professors L. Carmignani (Siena), R. Compagnoni (Torino), L. Cortesogno (Genova), G. Piccarreta (Bari) and R. Spiess (Padova) has been very useful. The Italian Council of Research (CNR) and the Ministry of Education (MIUR and formerly MURST) are acknowledged for having supported in the last decades several research projects on the BCs exposed in Italy.

\section{References}

This list mainly includes cited review papers, and not the papers marked by an asterisk in the text. The full list of the cited papers may be requested to the authors of the present paper (raffaele.sassi@unipd.it).

Anonimous, eds., 1985, Geochronology in Italy: results and problems: Rendiconti della Società Italiana di Mineralogia e Petrologia, v. 40, 226 pp.

Boriani, A., Giobbi Origoni, E., Borghi, A., and Caironi, V., 1990b, The evolution of the 'Serie dei Laghi' (Strona-Ceneri and Scisti dei Laghi): the upper component of the Ivrea-Verbano crustal section; Southern Alps, Northern Italy and Ticino, Switzerland: Tectonophysics, v. 182, pp. 103118.

Boriani, A., Giobbi Origoni, E., and Pinarelli, L., 1995, Paleozoic evolution of Southern Alpine crust (Northern Italy) as indicated by contrasting granitoid suites: Lithos, v. 35, pp. 47-63.

Boriani, A., and Villa, I., 1997, Geochronology of regional metamorphism in the Ivrea-Verbano Zone and Serie dei Laghi, Italian Alps. Schweizerische Mineralogische und Petrographische Mitteilungen, v. 77, pp. 381-401.

Caggianelli, A., and Prosser, G., 2002, Thermal perturbation of the continental crust after intraplating of thick granitoid sheets: a comparison with the crustal sections in Calabria (Italy): Geological Magazine, v. 139, pp. 699706.

Caironi, V., Colombo, A., and Tunesi, A., 2002, Protoliths of the basement rocks in the Orobic area (Central Alps): Memorie della Società Geologica Italiana, v. 57, pp. 1-9.

Carmignani, L., and Sassi, F.P., eds., 1992, Contribution to the Geology of Italy, with special regard to the Paleozoic basements: IGCP Project 276, Newsletter, v. 5, 486 pp.

Carmignani, L., et al., 2001, Geologia della Sardegna, Note Illustrative della Carta Geologica della Sardegna alla scala 1:200.000: Memorie descrittive della Carta Geologica d'Italia, v. 40, 285 pp.

Colombo, A., and Tunesi, A., 1999, Pre Alpine metamorphism of the Southern Alps west of the Giudicarie Line: Schweizerische Mineralogische und Petrographische Mitteilungen, v. 79, pp. 63-77.

Flügel, H.W., Sassi, F.P., and Grecula, P., eds., 1987, Pre-Variscan and Variscan events in the Alpine-Mediterranean mountain belts: Regional Contributions: IGCP no. 5, Mineralia Slovaca, 488 pp.

Fornelli, A., Piccarreta, G., Del Moro, A., and Acquafredda, P., (2002): Multi-stage melting in the lower crust of the Serre (Southern Italy): Journal of Petrology, v. 43, pp. 2191-2217.

Frey, M., Desmons, J, and Neubauer, F., eds., 1999, The new metamorphic map of the Alps: Schweizerische Mineralogische und Petrographische Mitteilungen.: v. 79, 230 pp.

Giobbi Mancini, E., Boriani, A., and Villa, I., 2003, Pre-Alpine ophiolites in the basement of Southern Alps: the presence of a bimodal association (LAG-leptyno-amphybolitic group) in the Serie dei Laghi (N-Italy, Ticino-CH): Rendiconti dell'Accademia Nazionale dei Lincei, v.14 (in print).

Grässner, T., and Schenk, V., 2001, An exposed Hercynian deep crustal section in the Sila Massif of Northern Calabria: mineral chemistry, petrology and a P-T path of granulite-facies metapelitic migmatites and metabasites: Journal of Petrology, v. 42, pp. 931-961.

Matte, P., 1991, Accretionary history and crustal evolution of the Variscan belt: Tectonophysics, v. 196, pp. 309-337. 
Meli, S., and Sassi, R., 2003, Petrography, age and geochemistry of the buried "Venice Granodiorite" (Northern Italy): Schweizerische Mineralogische und Petrographische Mitteilungen, v.13, pp. 57-61.

Miller, Ch., and Thöni, M., 1997, Eo-Alpine eclogitisation of Permian MORB-type gabbros in the Koralpe (Eastern Alps, Austria): new geochronological, geochemical and petrological data: Chemical Geology (Isotope Geoscience Section), v. 137, pp. 283-310.

Pandeli, E., Gianelli, G., Puxeddu, M., and Elter, F.M., 1994, The Paleozoic basement of the Northern Apennines: stratigraphy, tectono-metamorphic evolution and Alpine hydrothermal processes: Memorie della Società Geologica Italiana, v. 48, pp. 627-654.

Peccerillo, A., and Sassi, F.P., eds., 1994, Some contributions on the Circummediterranean crystalline basements and granitoids: Periodico di Mineralogia, v. 63, 280 pp.

Prosser, G., Caggianelli, A., Rottura, A., and Del Moro, A., 2003, Strain localisation driven by marble layers: the Palmi shear zone (CalabriaPeloritani terrane, southern Italy): GeoActa (in print).

Quick, J.E., S. Sinigoi, and Mayer, A., 1995, Emplacement of mantle peridotite in the lower continental crust, Ivrea-Verbano zone, northwest Italy: Geology, v. 23(8): pp. 739-742.

Rivalenti, G., Rossi, A., Siena, F., and Sinigoi, S., 1984, The Layered Series of the Ivrea-Verbano igneous complex. Western Alps, Italy: Tschermaks Mineralogische Petrogrographische Mitteilungen, v. 33, pp. 77-99.

Rottura, A., Caggianelli, A., Campana, R., and Del Moro, A., 1993, Petrogenesis of Hercynian peraluminous granites from the Calabrian Arc, Italy: European Journal of Mineralogy, v. 5, pp. 737-754.

Sassi, F.P., and Zanferrari, A., eds., 1989, Pre-Variscan and Variscan Events in the Alpine-Mediterranean belts: Stratigraphic Correlation Forms: Rendiconti della Società Geologica Italiana, v. 12, pp. 95-436.

Sassi. F.P. et al. eds., 2003, The abundance of 55 chemical elements and petrovolumetric models of the crust in 10 type areas from the cristalline basement of Italy (with some geophysical and petrophysical data): Accademia Nazionale delle Scienze, Scritti e Documenti, v. 32 (in print).

Spiess R., Bertolo, B., Borghi, A., and Tinor Centi, M., 2001, Crustal mantle lithosphere decoupling as a control of the Variscan metamorphism within the Eastern Alps: Australian Journal of Earth Sciences., 48, pp. 479-486.

Stampfli, G.M., von Raumer, J., and Borel, G.D., 2002, Paleozoic evolution of pre-Variscan terranes: from Gondwana to the Variscan collision: Geological Society of America Special Paper, v. 364, pp. 263-280.

Thöni, M., 1999, A review of geochronologic data from the Eastern Alps Schweizerische Mineralogische und Petrographische Mitteilungen, v. 79, pp. 209-230.

Vai, G.B., and Martini, I.P., eds., 2001, Anatomy of an Orogen: the Apennines and adjacent Mediterranean basins; Kluwer Academic Publishers, 634 pp.

von Raumer J.F., and Neubauer, F., eds., 1993, Pre-Mesozoic Geology in the Alps, Springer-Verlag, pp. 678

von Raumer, J.F, Stampfli, G.M., Borel, G.D., and Bussy, F., 2002, Oganization of pre-Variscan basement areas at the north-Gondwana margin: International Journal of Earth Sciences, v. 91, pp. 35-52.

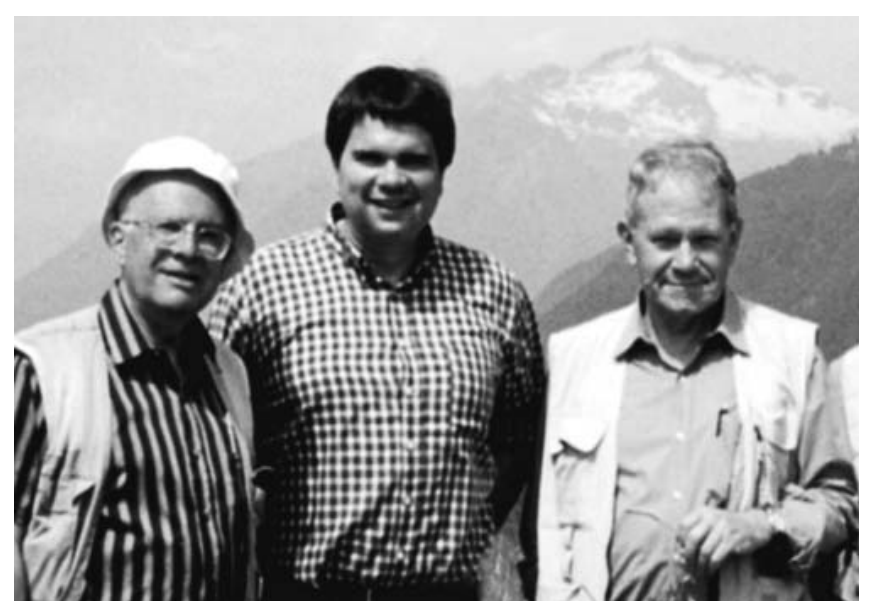

Attilio Boriani (on the right) is full professor of Petrology at the Department of Earth Sciences of the University of Milano. His main research interest is the metamorphic and igneous evolution of the continental crust, with special attention to the Alps. He was member of the Geological Committee of the National Research Council (1976-1981). He has been Vice-President from 1992 to 1996 and Secretary General of the IUGS from 1996 to 2002. He is a member of the Italian National Academy (of Lincei). He is currently President of the 32nd International Geological Congress.

Francesco Sassi (on the left) is full Professor of Petrography at the Department of Mineralogy and Petrology of the University of Padova. He led several national research projects concerning the basements in Italy from 1982 to 1999, and two IGCP projects on the Circum-Mediterranean basements (Leader of No. 5 and co-leader of No. 276). He also studied the petrologic mineralogy of white micas. He is a member of the Italian National Academy (of Lincei). In 1995 he received the National Prize for Physical, Mathematical and Natural Sciences.

Raffaele Sassi (in the middle) from 1993 is lecturer of "Lithology and Geology" at the Faculty of Engineering, University of Padova. He studied the evolution of crystalline basements in the Eastern Alps, Sardinia, Calabrian-Peloritan Mountains, Slovakia and Hungary. His research activity includes also the compositional variations of metamorphic phyllosilicates, as a function of intensive and extensive variables in low-grade metamorphism. Since 2002 he has been Secretary General of the IUGS Commission on Systematics in Petrology (CSP). 